\title{
Agama, Modernisasi, dan Teori Kritis: Sebuah Potret Pertautan
}

\author{
Prihatanto \\ Alumni Sekolah Tinggi Filsafat Driyakarya, Jakarta
}

\begin{abstract}
In the discourses of contemporary social and humanitarian sciences, Jurgen Habermas cannot be ignored. His works have been influential not only in social sciences and philosophy, but also in other sciences, including theology. In this context, theology of every religion may be completed based on The Habermas paradigm, namely the theory of Communicative Action. This effort should be done as a dialog between theology and the development of contemporary sciences, so that theological statements can be expressed communicatively to the present peoples. Through the assistance of critical theories, religious institution together with theological apparatus should not be alienated from the experience of modern people. Theology should be as such communicative that it is reasonable for its proponents.
\end{abstract}

Keywords: Modern People, Science, Theology

Keberlakuan universal sebuah ajaran

memang mengikat secara universal, maka harus diadakan diskursus antara semua bersama anggota masyarakat. Dengan kata yang tersangkut, secara bebas dari tekanan, lain, ajaran moral dalam setiap institusi agama adalah benar jika bisa digeneralisasikan. Menggeneralisasikan ajaran berarti memperlihatkan bahwa ajaran itu berlaku untuk semua orang (universal). Ini berarti jika bisa ditunjukkan bahwa suatu ajaran bersifat umum, ajaran itu sah sebagai ajaran moral. Institusi agama sebagai sebuah komunitas sangat memerlukan suatu proses diskursus. Karenanya, agama dan perangkat teologinya memerlukan suatu prosedur yang disediakan oleh teori kritis Habermas, dengan perhatian pada suatu tindakan komunikatif. Teori tindakan komunikatif ini merupakan prosedur yang layak bagi pembenaran suatu norma moral setiap institusi agama dalam situasi masyarakat modern yang pluralistik. Apabila hendak dipastikan apakah sebuah norma dengan kesediaan untuk hanya memberlakukan norma yang betul-betul berlaku universal dalam masyarakat pluralistik. Keberlakuan universal norma-norma harus dipastikan secara diskursif.

\section{Teori Kritis Jürgen Habermas}

Dalam teori tindakan komunikatif, Habermas menyatakan bahwa tindakan manusia yang paling dasar adalah tindakan komunikatif atau interaksi. Tujuan komunikasi adalah saling pengertian. Habermas membedakan dua tindakan, yaitu tindakan demi sasaran dan demi pemahaman. Tindakan demi sasaran dibagi lagi menjadi tindakan strategis (diarahkan pada manusia) dan instrumental (diarahkan pada alam). Tindakan demi pemahaman dapat ditemukan 
secara khas dalam komunikasi antar manusia. Tindakan demi pemahaman ini bukan monologis, tapi dialogis. Habermas menyatakan bahwa dalam tindakan komunikatif ini terjadi suatu "ideal role taking".

Menurut Habermas, dalam komunikasi itu para partisipan ingin membuat mitra bicaranya memahami maksudnya dengan berusaha mencapai apa yang disebutnya 'klaim-klaim kesahihan'. Supaya komunikasi dapat berhasil, maka orang harus berbicara dengan jelas, benar, jujur dan tepat, sehingga hubungan antar manusia yang betul-betul rasional dan bebas tetap dapat berlangsung.

Masyarakat komunikatif di atas bukanlah masyarakat yang melakukan kritik lewat revolusi kekerasan, melainkan lewat argumentasi demi konsensus. Namun haruslah diingat bahwa konsensus mendapatkan konteksnya dalam suatu diskursus rasional. Konsensus harus tetap terbuka untuk kritik dan pembaruan. Jika konsensus diterima sebagai kata akhir, maka komunikasi tidak lagi memainkan peran pertukaran pendapat dan demokrasi. Habermas menyediakannya dalam prosedur etika diskursus. Norma-norma moral dalam setiap agama yang semula dianggap benar, tentunya harus tetap dipersoalkan legitimasinya. Berbagai norma itu perlu dipastikan kembali secara rasional. Hal ini harus dihasilkan melalui suatu diskursus secara rasional. Semua anggota menjadi bebas dan sederajat, tanpa merasa terpaksa atau dipaksa terlibat dalam pengambilan keputusan bersama. Etika diskursus bertujuan untuk memastikan kesahihan suatu norma moral yang dipermasalahkan sampai tercapai konsensus di antara peserta. Tujuan ini dicapai lewat praktik komunikasi. Dalam praktik komunikasi itu, perhatian peserta diskursus dipusatkan pada kehendak untuk mencapai konsensus secara rasional. Kesahihan kemudian dapat dipastikan dan diperoleh lewat pertukaran argumentasi rasional dalam diskursus.

Menurut Habermas, lewat pertukaran pendapat antara anggota masyarakat, tercapailah suatu konsensus bersama. Kenyataan ini menunjukkan bahwa semua anggota masyarakat bukanlah penonton pasif. Yang dikehendaki dalam diskursus adalah anggota masyarakat secara aktif menyatakan perannya dalam kata dan tindakan demi suatu konsensus bersama. Dengan kata lain, mengacu pada Habermas, kelompok sosial (termasuk institusi agama) yang mampu bertahan dalam era globalisasi kini hanyalah organisasi sosial yang ada berdasarkan komunikasi timbal balik dengan menghargai kebebasan dan kesamaan derajat masing-masing anggota. Kita melihat bahwa dalam suatu komunikasi yang terbuka dan bebas, terdapat jaminan bahwa manusia dapat mempertahankan sebuah ruang yang bebas dari pemaksaan. Dengan demikian, tepatlah kalau setiap institusi agama (yang merasa berkepentingan pada pembelaan masyarakat yang terbuka, bebas dan menghormati martabat manusia), mengikuti gagasan Habermas itu melalui "rasio komunikatif".

\section{Peranan Teori Kritis untuk Ajaran Moral dalam Agama}

Ajaran moral dalam setiap agama secara sederhana dapat dipahami sebagai dialog agama dengan modernitas. Ajaran moral dalam setiap agama kerap mempunyai pengaruh cukup besar, tapi kerap juga mempunyai beberapa kelemahan, antara lain: masalah penafsiran, inkonsistensi antara teori dan praktik, kurangnya teori sosial serta keterbatasan kitab suci. Para teolog dari setiap agama de facto kerap mencari jawaban dalam dan lewat kitab 
Agama, Modernisasi dan Teori Kritis sebuah Potret Pertautan; Prihatanto

suci. Padahal, tidak semua permasalahan sosial-moral di dunia dapat dijawab lewat dan dalam kitab suci. De facto, agama kontemporer saat ini harus berhadapan dengan pelbagai implikasi zaman, misalnya perang nuklir, clonning, dan berbagai kemajuan iptek. Kitab suci tidak lagi menjadi satu-satunya jawaban final bagi berbagai permasalahan manusia. Dengan kata lain, berbagai prinsip moral yang diajarkan oleh setiap agama baru menjadi nyata, jika dalam institusi agama sendiri konflik-konflik tidak lagi diselesaikan menurut "garis kuasa suci" dari atas (entah bernama hirarki, entah dewan syuro, dan sebagainya), tapi mulai digumuli dengan menghargai orang lain dan pendapatnya. Berangkat dari kesadaran perlunya saling pemahaman dalam setiap institusi agama, teori tindakan komunikatif Habermas dapat melengkapi ajaran moral setiap agama dengan perhatiannya pada kepentingan emansipatoris masyarakat.

Segala pertimbangan, kritik dan pemikiran timbal balik sangat diperlukan untuk mencari kesepahaman dan kebenaran suatu ajaran sosial-moral dalam setiap agama. Berbagai ajaran moral dalam agama seharusnya terus menerus dipertimbangkan dan dicari kebenarannya secara bersama. Ini mengandaikan bahwa para tokoh agama mengakui keberadaan mitra bicaranya apa adanya, sehingga pesan profetis agama kepada dunia tidak tampak kaku, berlebihan dan tidak akan diremehkan oleh masyarakat.

Dalam setiap agama, perangkat teologi sebagai ilmu, muncul dalam hubungan antara obyek (teks), konteks (dunia) dan penafsir (teolog). Teologi kerap memiliki problem hermeneutik (berada dalam ancaman perangkap pikiran deduktif dan apriori). Para penafsir (teolog) bersifat aktif dalam hubungannya dengan obyek (teks) yang diketahui. Pada saat yang sama, para teolog itu dalam arti tertentu merupakan 'obyek-obyek' bagi dunia mereka, karena mereka dibentuk oleh konteks kebudayaan/ lingkungan.Oleh karena itu, teologi memerlukan pengujian dengan menggunakan hermeneutik kritis dan tunduk pada rasionalitas.

Hermeneutik kritis dan rasionalitas ini disediakan oleh teori kritis Habermas, dengan analisis utamanya pada bahasa. Kita sadar akan kerapuhan bahasa manusia untuk menafsir dan mengkomunikasikan buah pikirannya, maka kita perlu membuat reinterpretasi terhadap proses komunikasi yang selama ini dipakai dalam berteologi. Reinterpretasi tersebut dapat dilakukan dengan bantuan teori kritis Habermas, yang sangat menghargai terjadinya kelancaran bahasa antar perseorangan yang bebas. Teori kritis sungguh-sungguh berguna sebagai sebuah mediasi bagi teologi. Teologi sendiri adalah peralatan ilmiah (ilmiah mengandung arti pengetahuan yang tepat, kritis dan rasional) untuk melihat kenyataan yang disebut "institusi agama". Karena institusi agama dan dunia harus secara aktual saling berhubungan dengan tepat, maka pendekatan kritis perlu dilakukan sehingga dapat membantu setiap agama dalam tugas syiarnya di dunia.

Di lain pihak, kalau pendekatan kritis tidak dilakukan, justru institusi agama dapat berubah menjadi sedemikian mutlak dan tidak lagi menghargai dunia. Sebaliknya, dunia juga dapat menjadi sedemikian mutlak dan menolak makna yang disampaikan oleh setiap agama kepadanya. Oleh karena itu, hubungan timbal balik yang tepat dari pelbagai disiplin ilmiah untuk menyoroti dunia dan agama merupakan sesuatu yang tidak dapat ditawar-tawar lagi. Pentingnya hubungan timbal balik ini menghadapkan teologi dengan filsafat, khususnya teori kritis sebagai sarana untuk memahami dunia 
secara memadai. Bila yang ingin kita ketahui adalah hubungan agama dengan masyarakat dan berbagai permasalahannya, kita jangan mengambil pengetahuan sederhana tentang masyarakat sebagai titik tolak kita, karena pengetahuan semacam itu sudah diresapi oleh ideologi yang berlaku dalam masyarakat itu. Kita harus mengambil pemikiran kritis dan analitis yang dapat menjelaskan hubungan sebab akibat, dinamisme dan berbagai kekuatan yang bekerja dalam masyarakat sebagai titik tolak kita. Pemikiran kritis ini disediakan oleh teori kritis Habermas, dengan etika komunikatifnya. Dengan kata lain, teori kritis bisa menyingkapkan berbagai faktor kunci yang menjelaskan fakta sosial dan memungkinkannya untuk memberikan pelbagai diagnosis untuk mengatasi berbagai permasalahan dalam masyarakat dan agama. Perhatian setiap agama terhadap suatu praksis komunikatif, sebagai sebuah perhatian yang sungguh tidak mengada-ada bilamana agama memang mau tetap diperhitungkan dalam kehidupan pascamodernitas ini.

\section{Tradisi, Teologi dan Diskursus}

Tradisi adalah kategori penting dalam pemikiran setiap agama yang meneruskan pewartaan para nabi/rasul. Tradisi menyangkut iman dan moral, yang berkaitan dengan ilmu teologi. Jika agama ingin maju, tradisi harus terus diinterpretasi dan direfleksikan sesuai dengan zamannya. Interpretasi dan refleksi atas warisan tradisi ini harus terjadi dalam suatu proses diskursus rasional dan terbuka. Diskursus sendiri adalah pembicaraan bersama untuk memastikan kesahihan sebuah norma yang dipermasalahkan untuk mencapai suatu konsensus rasional. Proses diskursus atau pembicaraan bersama demi suatu konsensus rasional terhadap tradisi ini terjadi dalam institusi agama, yang kenyataannya tersusun atas berbagai orang dengan peran yang berbeda-beda, sesuai dengan kapasitasnya masing-masing.

Diskursus adalah pembicaraan bersama untuk memastikan kesahihan sebuah norma yang dipermasalahkan. Kita melakukan diskursus kalau mengandaikan kemungkinan untuk mencapai suatu konsensus rasional. Teologi sendiri termasuk dalam kategori diskursus teoretis karena para teolog ingin mencapai konsensus atas klaim kebenaran. Hal ini berarti bahwa kebenaran dicapai melalui konsensuskonsensus rasional lewat subyek-subyek yang berkompeten. Karenanya, proses argumentasi menjadi penting. Sebab lewat proses argumentasi atau tukar pendapat secara rasional, pelbagai klaim akan validitas bisa diakui, diterima ataupun ditolak.

Implikasi teori kritis Habermas jelas yaitu semua teolog dan umat awam dalam setiap agama dapat meneliti, mengajar, menyebarkan serta mendiskusikan pelbagai interpretasi doktrin, semuanya dalam atmosfer yang bebas dominasi. Pelbagai pernyataan para pemimpin agama yang kerap disebut "karisma kebenaran yang mutlak" perlu mempunyai pendasaran ilmiah. Berbagai pernyataan mereka perlu menjadi obyek diskursus rasional bagi semua anggotanya. Hal ini tidak mengurangi wibawa para pemimpin agama, tetapi menandakan bahwa wewenang mereka harus disalurkan melalui tindakan tuturan dalam atmosfer tindakan komunikatif, terutama dalam hal pembuatan keputusan publik.

Tradisi dalam setiap agama patut dihargai sebagai mitra refleksi yang terus berkembang, bukan sebagai kebenaran tunggal yang kekal abadi. Pengalaman aktual-eksistensial setiap agama pada 
Agama, Modernisasi dan Teori Kritis sebuah Potret Pertautan; Prihatanto

zaman ini menjadi titik pijak untuk berdialog dengan kitab suci dan tradisi. Keberagamaan yang sesungguhnya berangkat dari sebuah relasi antar pribadi, sebuah komunitas komunikatif dengan bahasa berdasar makna-makna utopis yang berpusat pada tokoh (entah Sidharta Gautama, Muhammad, Yesus orang Nazareth, dan sebagainya), memerlukan mediasi dari teori kritis Habermas

Atas dasar itu, tepatlah kalau pelbagai pernyataan moral para pemimpin agama harus selalu terbuka pada tanggapan kritis, diskusi, koreksi dan ditampilkan sebagai sebuah praksis komunikasi. Agama perlu menciptakan lingkup kehidupan yang memungkinkan mudahnya interaksi. Interaksi yang berdasarkan saling pengertian dan kaya akan kontak sosial. Pengambilan keputusan publik dalam agama yang melibatkan seluruh anggota masyarakat sekurang-kurangnya rancangan keputusan yang terbuka untuk kritik masyarakat malah menjadikan setiap pernyataan moral agama itu lebih dapat diterima dan dilaksanakan.

\section{Etika Diskursus}

Ajaran moral yang tepat dalam hidup keseharian kita sebisa mungkin harus menjawab sejumlah pertanyaan, yakni apakah ajaran moral tersebut menyentuh pengalaman keseharian, apakah ajaran moral tersebut sungguh rasional dan dapat dibuktikan, dan apakah ajaran moral tersebut benar-benar dibuat secara tulus.

De facto, berbagai pernyataan moral dalam setiap agama selama ini kerap dibuat oleh kaum elitis (entah para klerus, kyai, rahib-biksu). Padahal, bisa jadi mereka kurang berwenang dan kurang mampu untuk membuat pernyataan moral dalam multidimensi kehidupan masyarakat, sehingga kerap kurang menyentuh pengalaman hidup keseharian. Berangkat dari fenomena di atas, perlu adanya suatu diskursus moral yang terbuka dan bebas bagi seluruh anggota. Dalam diskursus moral, para ahli etika (termasuk dari kaum awam/sekular) harus menyumbangkan pemikiran mereka, dan para pemimpin agama mendengarkan semua argumentasi rasional mereka. Pemimpin agama dapat menjadi pemegang keputusan akhir yang resmi (semacam hakim), setelah mendengarkan pembicaraan bersama yang terjadi dalam diskursus tersebut. Dengan demikian, ajaran moral dari suatu agama yang ingin dinyatakan secara publik haruslah melewati suatu jalur argumentasi. Jalur argumentasi menawarkan suatu tata sosial yang rasional, adil, bebas serta terbuka. Argumentasi adalah cara untuk mempertanggungjawabkan dan memastikan rasionalitas berbagai pernyataan moral tersebut. Praksisnya yaitu dengan etika diskursus.

Berbagai pertanyaan moral tidak dapat dijawab oleh agama dengan mengacu pada tradisi dan kitab suci saja. Yang diperlukan adalah memastikan kembali moralitas yang dapat diyakini oleh semua anggotanya. Dengan demikian, para pemimpin agama dengan wewenang mengajarnya juga memerlukan suatu konsensus yang berasal dari diskursus rasional yang terbuka bagi semua anggota, sehingga berbagai pernyataan moralnya sungguh-sungguh berarti banyak bagi masyarakat luas. Dalam situasi ini, etika diskursus menjadi sarana untuk menetapkan norma-norma moral yang dapat diakui keberlakuannya oleh semua.

Etika diskursus Habermas merupakan sarana refleksi sistematis yang layak untuk memastikan keabsahan ajaran moral dalam setiap agama. Norma-norma moral sahih kalau sanggup disepakati oleh semua yang tersangkut dalam sebuah diskursus. 
Pertanyaan yang mau dijawab Habermas lewat etika diskursus ini adalah "Bagaimana pelbagai norma moral dapat dipertanggungjawabkan secara rasional?" Baginya, hanya norma yang dapat diberlakukan secara universal dapat dianggap bersifat moral. Prinsip itu dirumuskannya dalam prinsip Universalisasi (U). Berdasarkan prinsip itu, norma menjadi sahih hanya jika:

"semua pihak yang (mungkin akan) terkena dampak kepatuhan umum atas norma dapat menerima konsekuensi dan efek sampingnya, yang diharapkan dapat memenuhi kepentingan setiap orang."

Berdasarkan kutipan di atas, terdapat ide dasar di balik prinsip Universalisasi (U) yaitu pengandaian suatu kemauan dan kemampuan untuk terlibat dalam upaya memahami yang lain. Upaya untuk memahami yang lain ini ditempuh setelah setiap orang menjadi paham mengenai kepentingannya dan mendapatkan kesempatan yang sama untuk mengungkapkan hal itu. Jika dalam proses itu dicapai sebuah konsensus rasional, konsensus tersebut harus diterima sebagai kepentingan umum oleh semua pihak yang terlibat. Dasar penerimaan sebuah norma sebagai kepentingan umum terletak pada rasionalitas kepentingan itu berhadapan dengan kepentingan-kepentingan lain. Untuk memastikan persetujuan itu, terdapat satu cara, yakni diskursus. Diskursus sendiri adalah pembicaraan bersama untuk memastikan berbagai norma moral yang dipermasalahkan. Prinsip diskursus (D) Habermas berbunyi:

"Norma-norma dapat diklaim sebagai sahih kalau mendapatkan persetujuan dari semua peserta yang kemungkinan terkena dampak dari norma itu dalam suatu diskursus praktis".
Dari prinsip di atas, dapat dikatakan bahwa kesahihan sebuah norma yang dipermasalahkan haruslah dipastikan lewat diskursus oleh semua peserta yang kemungkinan terkena dampak dari norma itu. Norma moral baru menjadi sahih setelah norma itu mendapatkan persetujuan dari semua peserta diskursus. Metodenya adalah praksis komunikasi, yang melibatkan semua pihak yang tersangkut untuk melakukan pembicaraan bersama dengan kesempatan yang sama untuk mengemukakan pendapat.

Mekanisme ini mengantar peserta diskursus, yang tidak memiliki argumentasi rasional yang memadai untuk mengakui argumentasi rasional lain yang lebih memadai. Dengan demikian, dapat dikatakan bahwa kesahihan sebuah norma bersifat intersubyektif. Etika diskursus memberi ruang untuk hubungan sosial, tempat semua golongan saling berbaur, saling memperkaya, saling menerima, dan saling memahami perbedaan dalam suatu semangat solidaritas.

\section{Penutup}

Menurut teori kritis, akal budi manusia dewasa ini dapat berada dalam kemacetan total. Hal ini disebabkan karena akal budi itu kerap digunakan secara instrumental, dan selalu mengorientasikan manusia untuk mencapai hasil-hasil atau sasaran saja. Itulah rasionalitas instrumental. Habermas berpendapat, manusia bisa keluar dari kemacetan itu, jika ia mau memalingkan pemikirannya pada paradigma lain. Paradigma lain itu, yakni paradigma komunikasi manusia. Dalam paradigma komunikasi terkandung potensi, di mana manusia tidak diperbudak oleh hasrat untuk menguasai. Tapi, manusia dituntun untuk saling memahami dan mengerti. 
Agama, Modernisasi dan Teori Kritis sebuah Potret Pertautan; Prihatanto

Dengan demikian, semua pihak yang terlibat dalam suatu tindakan komunikatif, wajib mencari kesepahaman dan kebenaran suatu ajaran moral lewat pertimbangan, kritik dan pemikiran timbal balik. Ajaran moral itu tidak begitu saja ada sejak semula, tetapi terus menerus dipertimbangkan dan dicari kebenarannya secara bersama. Hal ini mengandaikan bahwa seseorang mengakui keberadaan mitra bicaranya. Habermas membuka perspektif lain, dengan suatu teori tindakan komunikatif, di mana orang saling mencari pengertian bersama (konsensus) demi kepentingan bersama. Dalam suatu pembicaraan bersama, orang harus bebas dari aspek distortif bahasa (bebas dari aspek ketidaktepatan bahasa). Bebas atau otonom tidak hanya dalam arti bebas dari paksaan eksternal atau manipulasi tetapi juga bebas dari paksaan internal atau penipuan diri, dalam upaya membangun konsensus rasional atas norma. Dalam masyarakat yang pluralistik seperti sekarang ini, penetapan berbagai ajaran moral dan sosial dalam setiap agama tidak dapat dikembalikan begitu saja kepada para pemimpin agama-entah dewan syuro, hirarki, dan lain sebagainya (dalam bahasa Habermas: Norma-norma moral itu tidak dapat lahir dari tindakan strategis, melainkan hanya dari tindakan komunikatif). Norma-norma moral hanya dapat memperoleh status sebagai sahih kalau sanggup disepakati oleh semua pihak yang tersangkut dalam sebuah diskursus. Maka, diskursus yang rasional, terbuka, serta bebas dari dominasi perlu terus ditingkatkan dalam setiap agama.

Pada kenyataannya, sudah sangat jelas bahwa institusi agama dengan perangkat teologi yang hanya berusaha merumuskan kembali - secara metode dan sistematis - rumusan dari tradisi, khususnya kitab suci, tidak memenuhi syarat ilmiah zaman sekarang. Teologi memang perlu merumuskan kembali tradisi dalam rumusan yang sesuai dengan bahasa orang sezamannya. Teologi juga perlu melakukan interdisiplinaritas dengan berbagai ilmu lain.

Adalah merupakan fakta bahwa dalam masyarakat sekarang ini terdapat banyak nilai yang berbeda, dan sering kali perbedaan itu menjadi sumber disintegrasi sosial jika tidak dicarikan suatu pemecahan yang memuaskan bagi semua pihak. Di tengah pluralitas pandangan, nilai dan kepentingan, mekanisme teori kritis Habermas merupakan jawaban telak atas konflik kepentingan. Mekanisme ini mengajukan model pemecahan yang ideal yang membiarkan konflik terjadi dalam dinamika pertukaran ide. Setiap orang merasa bebas dan sederajat dalam berargumentasi untuk posisinya, sampai suatu prinsip umum ditetapkan bersama-sama demi kepentingan bersama pula.

Mekanisme teori kritis Habermas yang menekankan hubungan antar manusia yang terbuka dan rasional sangat berguna bagi perkembangan setiap institusi agama sebagai sebuah masyarakat yang komunikatif. Jika agama masih ingin berperan bagi masyarakat modern, maka mereka tidak dapat melampaui apalagi meniadakan upaya yang rasional dan manusiawi ini.

\section{Daftar Pustaka}

Deflem, M. (ed.), 1996, Habermas, Modernity and Law, London: SAGE Publications LTD.

1991. Moral Consciousness and Communicative Action. Cambridge: The MIT Press.

Hardiman B. F. 1993. Kritik Ideologi: Pertautan Pengetahuan dan Kepentingan. Yogyakarta: Kanisius. 
UNISIA, Vol. XXX No. 64 Juni 2007

Magnis-S. F. 2000. 12 Tokoh Etika Abad ke-20. Yogyakarta: Kanisius.

Milbank, J. 1990. Theology and Social Theory: Beyond Secular Reason. Oxford, Cambridge and Massachusetts: Blackwell.

Regh, W. 1994. Insight and Solidarity: A Study in the Discourse Ethics of Ji'rgen Habermas. California: University of California Press.
Seran, A. 1995. On Habermas Discourse Ethics. Manila, Ateneo de Manila University.

Tilley, T. W. 1995. Postmodern Theologies: The Challenge of Religious Diversity. New York:Orbis Books. 